\title{
Role of Complementary and Alternative Medicine in Prevention and Treatment of COVID-19: An Overhyped Hope
}

\author{
Abhishek Shankar ${ }^{1}$, Anusha Dubey ${ }^{2}$, Deepak Saini ${ }^{2}$, and Chandra Prakash Prasad ${ }^{3}$
}

The entire mankind across the globe is suffering with COVID-19 outbreak and searching for definite vaccine or treatment for it. Every country is trying hard to get a breakthrough for definitive therapy in the form of antiviral therapy, plasma therapy and vaccine against this virus, as current management is symptom directed treatment. Many of the countries are also trying complementary and alternative medicine (CAM), including traditional, Herbal treatment, alone or in combination with standard management, as an option for prevention or treatment of COVID-19. Although, there is no conclusive evidence to support its usefulness to reduce the viral load and/or symptoms. Countries like China and India, have either started or preparing to conduct trial studies of traditional medicine to assess the efficacy of such therapies in coronavirus disease.

The China Government is promoting the use of traditional Chinese medicine (TCM) in COVID-19, and it is reported that around $85 \%$ patients used it with standard treatment. TCM was used to treat COVID-19 patients in Italy with the help of Chinese doctors. ${ }^{(1-3)}$ Historically, TCM has been used for infectious diseases for last many centuries based on clinical signs and symptoms along with its traditional indications. ${ }^{(2,3)}$ Many researches claimed of antiviral properties in TCM, but the choice of its use in COVID-19 is in experimental stage. ${ }^{(4)}$

One meta-analysis emphasised the effect of TCM for the prevention of COVID-19, which acts primarily on pneumonia-like symptoms. TCM in combination with Western medicines are recommended as a complementary treatment in SARS, as reported by a Chinese study in 2012, in which $58.3 \%$ confirmed patients of SARS showed a positive effect, ${ }^{(3)}$ whereas same combination improved the symptoms of pulmonary infiltration and quality of life of SARS patients in another study from China. ${ }^{(5)}$
The General Office of the National Health and Health Commission of China and the Office of the State Administration of Traditional Chinese Medicine issued a Diagnosis and Treatment Protocol for COVID-19, providing a systemic treatment with TCM, based on its effectiveness on preliminary clinical practice for severe pneumonia like symptoms also seen in COVID-19. Different prescriptions with different doses are recommended in different stages of the disease. ${ }^{(6)}$ Thus, TCM seems to be a potential breakthrough for drug discovery against COVID-19 in China.

Looking at the infectivity and severity of COVID-19, Ministry of AYUSH (Ayurveda, Yoga \& Naturopathy, Unani, Siddha and Homoeopathy), Government of India suggested measures that includes the use of homoeopathic medicine 'Arsenic Album 30C', Ayurveda preparations such as 'Kadha' (Ginger, curcumin, cloves, honey, fennel seeds, cumin seeds) and lukewarm water as an immunity booster. ${ }^{(7)}$ Pharmacological and non-pharmacological interventions are described in preventive measures defined in Ayurveda. Nonpharmacological interventions includes healthy lifestyles, adequate physical activity, enough sleep, sadvritta, and avoidance and isolation from infected persons. ${ }^{(8)}$ Some ayurvedic medicines like garlic (Allium sativum), turmeric (Curcuma longa), Carom or Ajwain (Trachyspermum ammi) can be used as a disinfectant for the prevention

(C)The Chinese Journal of Integrated Traditional and Western Medicine Press and Springer-Verlag GmbH Germany, part of Springer Nature 2020

1. Department of Radiation Oncology, Lady Hardinge Medical College and SSK Hospital, Delhi (110001), India;

2. Division of Cancer Control and Prevention, Indian Society of Clinical Oncology, Delhi (110049), India; 3. Department of Medical Oncology (Lab), Dr BR Ambedkar Institute Rotary Cancer Hospital, All India Institute of Medical Sciences, Delhi (110029), India

Correspondence to: Dr. Abhishek Shankar, E-mail: doc. abhishankar@gmail.com

DOI: https://doi.org/10.1007/s11655-020-2851-y 
of COVID-19. ${ }^{(9)}$ Substantial researches have shown antiviral properties of ayurvedic preparations which can be used for therapeutic management of COVID-19 patients. ${ }^{(10)}$ Strategies like community based intervention and mass prophylaxis can be helpful to reduce the respiratory infection. ${ }^{(11,12)}$

Previous studies have found effective use of homeopathic medicines to treat flu like symptoms, where Arsenicum album and Bryonia were found effective in symptoms like fever, cough, running nose, headache during H1N1 influenza in 2009. Similar results were also reported by other authors. ${ }^{(13,14)}$

As reported from Pune, ${ }^{(15)}$ India, COVID positive patients who were treated with combination of hydroxychloroquine and homeopathic medicine, reported reduction in recovery time with this combination. However, name of homoeopathic medicine was not disclosed. In Gujrat, India, ayurvedic preparation and homeopathic medicine were administered to 3,174 and 2,000 quarantined persons, respectively, to boost the immunity as a preventive measure to COVID-19. None of the persons who received the medication as per the guideline, developed signs and symptoms of COVID-19 during 14 days of quarantine and were reported negative for coronavirus infection. Gujrat government has issued a guidance regarding use of ayurvedic and homoeopathic medicine as an immune booster to prevent this virus infection. As of now more than 8 million people received 'Kadha' and more than 5 million people received arsenicum album 30 in the state of Gujrat in India.

Looking at the productivity of the result of this combination along with modern medicine, the government of Kerala, India started expending the facilities in AYUSH hospitals. ${ }^{(16)}$ Kerala decided to interlink the framework of traditional medicine with the public health administrative system to overcome this pandemic. The government of Kerala has approved the use of the traditional Ayurvedic medicinal system. This ayurvedic intervention includes 7 categories, 'Sukhayusham' for elderly person aged 60 years and older, while lighter form of exercises were planned under 'Swasthyam project'. This government also started AYUR RAKSHA CLINIC, to help improve quality of life of patients who recovered from COVID-19. ${ }^{(17)}$ For quarantined persons with no symptom, Sanjeevani vati, Chitrakadi vati and combination of Guduchi (Tinospora cordifolia), Shunthi (Zingiber officinale) and Haridra (Curcuma longa) were used for prophylaxis ${ }^{(18)}$ whereas, Lakshmi Vilas Rasa, ${ }^{(19)}$ Pippali rasayana, ${ }^{(20)}$ Sanjeevani vati, Chitrakadi vati, Go jihvaadi Kashaya, Vyaghri haritaki, Kantakaari Avaleha, Dashamul kwath, Sitopaladi were given for mild symptoms in COVID patients. ${ }^{(21)}$

Homoeopathic medicine 'Prevengho-VIR' was used in Cuba for high risk COVID-19 patients to prevent the severe respiratory symptoms, while Zimbabwe permitted the use of herbalist for COVID-19 treatment. In Madagascar, COVID-ORGANICS, containing medicine used to treat maliaria, has been promoted by government as an immunity booster against COVID-19. In Africa, traditional herbals are used widely against various infections and diseases like malaria. ${ }^{(22,23)}$

Use of Unani medicine as fumigants has been found effective, which can be used for control of transmission. ${ }^{(24)}$ In present situation, stress and anxiety due to coronavirus pandemic can be effectively managed by the practice of yoga and ayurvedic medicines. ${ }^{(25)}$ Some form of therapies like acupuncture and massage can be used effectively for symptomatic relief.

Although, US Centre for Disease Control and Prevention has stated that one of the best ways to prevent the infection is by avoiding contact with the diseased people. But, in the absence of any definitive treatment, CAM helps the general population to boost their immunity with no harm or side effects.

However, no clinical evidence of these alternative medicines to treat COVID-19, lack of high-quality data, little or no data to support their claims, lack of statistically significant number of participants, long term efficacy, proper follow-up, no comparative control groups and no adherence to strict quality norms while conducting clinical trials are some of the concerns expressed by experts. Therefore, unless research is not conducted as per standard protocols, CAM will be seen with a lot of skepticism in medical science.

\section{Conflict of Interest}

The authors declare no competing financial interests. 


\section{REFERENCES}

1. Cyranoski D. China is promoting coronavirus treatments based on unproven traditional medicines: Nature news 2020 [updated May 6; cited 2020 May 14]. Available from: https://www.nature.com/articles/d41586-020-01284-x.

2. Yang $Y$, Islam MS, Wang J, Li Y, Chen X. Traditional Chinese medicine in the treatment of patients infected with 2019-New coronavirus (SARS-CoV-2): a review and perspective. Int J Biological Sci 2020;16:1708-1717.

3. Zhang MM, Liu XM, He L. Effect of integrated traditional Chinese and Western medicine on SARS: a review of clinical evidence. World J Gastroenterol 2004;10:3500-3505.

4. Ling CQ. Traditional Chinese medicine is a resource for drug discovery against 2019 novel coronavirus (SARSCoV-2). J Integr Med 2020;18:87-88.

5. Liu X, Zhang M, He L, Li YP, Kang YK. Chinese herbs combined with Western medicine for severe acute respiratory syndrome (SARS). Cochrane Database Syst Rev 2006:Cd004882.

6. Li Y, Liu X, Guo L, Li J, Zhong D, Zhang Y, et al. Traditional Chinese herbal medicine for treating novel coronavirus (COVID-19) pneumonia: protocol for a systematic review and meta-analysis. Systematic Rev 2020;9:75.

7. Advisory for Corona virus from AYUSH Ministry [cited 2020 May 11]. Available from: https://pib.gov.in/ PressReleasePage.aspx?PRID=1600895\#.

8. P DN, ey. Seven shields of ayurveda between health and diseases. Annals Ayurvedic Med 2019;8:6-10.

9. Bhatwalkar SB, Shukla P, Srivastava RK, Mondal R, Anupam R. Validation of environmental disinfection efficiency of traditional Ayurvedic fumigation practices. $\mathrm{J}$ Ayurveda Integr Med 2019;10:203-206.

10. Vellingiri B, Jayaramayya K, lyer M, Narayanasamy A, Govindasamy V, Giridharan B, et al. COVID-19: A promising cure for the global panic. Sci Total Environ 2020;725:138277.

11. Patil A, Dindore P, Aziz A, Kadam A, Saroch V. Clinical effect of suvarna bindu prashan. J Ayurveda Integr Med Sci 2017;2:11-8.

12. Rastogi S, Lakhotia SC, Singh RH. Ayurvedic Rasayana therapy: a rational understanding necessary for mass benefits. In: Rastogi S, editor. Translational Ayurveda: Fundamentals and Modalities. Springer: Singapore; 2019:77-99.

13. Mathie RT, Baitson ES, Frye J, Nayak C, Manchanda RK, Fisher P. Homeopathic treatment of patients with influenzalike illness during the $2009 \mathrm{~A} / \mathrm{H} 1 \mathrm{~N} 1$ influenza pandemic in India. Homeopathy 2013;102:187-192.

14. Chakraborty P, Lamba C, Nayak D, John M, Sarkar D,
Poddar A, et al. Effect of individualized homoeopathic treatment in influenza like illness: A multicenter, single blind, randomized, placebo controlled study. Indian J Res Homoeopathy 2013;7:22-30.

15. Khelkar PP. Coronavirus: 18 nurses at Pune hospital test positive, doctor treats staff with $\mathrm{HCQ}$, homeopathy." Retrieved June 15, 2020, from https:// www.indiatoday.in/india/story/coronavirus-nursespunehospital-test-covid-19-positive-doctor-treats-staff-hcqhomeopathy-1668637-2020-04-19.

16. COVID-19 (nCorona) Virus Outbreak Control and Prevention State Cell Health \& Family Welfare Department Government of Kerala [cited 2020 May 11]. Available from: https://dhs.kerala.gov.in/wp-content/uploads/2020/03/Howto-convert-Hospital-into-COVID-Hospital.final-pdf.pdf.

17. Ayurveda will be used in the prevention and treatment-CM [cited 2020 May 14]. Available from: https://keralanews.gov. in/2842/Covid-19-ayurveda-.html.

18. Rani P, Sharma K, Kumar A. Probable mode of action of Sanjivani Vati - a critical review. Int J Health Sci Res 2018;8(8):295-307.

19. Srikanth N, Singh A, Ota S, Sreedhar B, Galib, Dhiman KS. Chemical characterization of an Ayurvedic herbo-mineral preparation-Mahalaxmivilas Rasa. J Ayurveda Integr Med 2019;10:262-268.

20. Bisht D, Sharma Y, Mehra B. A clinical study to evaluate the efficacy of Pippali Rasayana in certain respiratory disorders. AYU (An international quarterly journal of research in Ayurveda). 2009;30:337-341.

21. Makhija IK, Shreedhara CS, Ram HN. Mast cell stabilization potential of Sitopaladi churna: An ayurvedic formulation. Pharmacognosy Res 2013;5:306-308.

22. Lobine D. Do African herbal medicines hold hope for 2020 [updated April 20; cited 2020 May 12]. Available from: https://nef.org/2020/04/20/do-african-herbal-medicineshold-hope-for-covid19/.

23. WHO Africa: WHO supports scientifically-proven traditional medicine 2020 [updated May 4; cited 2020 May 12]. Available from: https://www.afro.who.int/news/whosupports-scientifically-proven-traditional-medicine.

24. Nikhat S, Fazil M. Overview of Covid-19; its prevention and management in the light of Unani medicine. Sci Total Environment 2020;728:138859.

25. Tillu G, Chaturvedi S, Chopra A, Patwardhan B. Public health approach of ayurveda and yoga for COVID-19 prophylaxis. J Altern Complement Med 2020;26:360-364.

(Accepted June 1, 2020) Edited by ZHANG Wen 